\title{
On the Civil society and the State of Law in Vietnam
}

\author{
Phan Xuan Son
}

\section{What is a Civil Society?}

"Civil society" is called "xã hội công dân" in Vietnamese, "Société civile" in French and "Zivilgesellschaft" in German. Among them, "civi"“, and "civile" are all adjectives that mean "belonging to the citizens, of the citizens' affairs." For example, civil law means "dân luật", civil rights means "quyền công dân" and civic liberty means "tự do công dân" in Vietnamese. ${ }^{1}$ Society may mean "association", "union”, "community", "organization” and "company". Its meaning is identical to that of "société" in French. Therefore, civil society is an assembly of citizens in the form of an "organization”, "community", "company”, “group”, “association”, "union” or "cooperative”.

When translated into Vietnamese it can be understood as either "xã hội công dân" (society of citizens) or "xã hội dân sự" (society for civil affairs). Both terms have their equivalent meanings in English. In the former case, civil society refers to the organizations, communities and networks of citizens. The latter term emphasizes that these organizations, communities and unions are related to the affairs of the citizens (civil affairs).

However "dân sự" (công việc của dân) in Vietnamese can have multiple meanings. First of all, depending on the contexts, "dân" can mean "citizens", "people" or "subject" ["ordinary person/people”, "ordinary subject/s", which

${ }^{1}$ Encyclopedia Publisher (2005): Tù điển Anh-Việt (English-Vietnamese Dictionary). Hanoi. 166. 
refer to a person or a group of people that are not the state (e.g in feudal periods)]. "Sự" means affairs or matters. However when combining "sự" with "dân", the resulting "dân sự" refers to the affairs of "dân” (which means people, citizens or subjects) which are different from and independent of those of the state. Meanwhile, the concept of "civil society" in the first place implies an organization and community of citizens who possess legal and political status in relation to the state. While "Dân sự" is sufficient to distinguish "civil affairs" (việc dân) with those of the state, it fails to indicate what political and legal relations the citizens in question have with the state. In other words the concept of "xã hội công dân" (society of citizens) is created as soon as people in societies acquire their rights and obligations, and after the introduction of capitalist states of law. On the other hand, "xã hội dân sự" refers to a non-state and civil sector and does not specify the relations between this sector and the state. A comparison can be made between "Xã hội dân sự" and "Xã hội công dân" and "Kinh tế hàng hóa" (commodity economy) and "Kinh tế thị trường" (market economy) in economics, respectively. "Xã hội dân sự” denotes a general non-state sector in society, while "xã hội công dân" refers to this sector but only after the introduction of the capitalist states of law (not heretofore). This difference is primarily caused by the Vietnamese language. In English, Russian, France and other languages there is no such a case and only the equivalent of "xã hội công dân" in Vietnamese exists.

Thus while "xã hội dân sự" conveys a broader meaning, its political and legal connotations are opaque. Its counterpart "Xã hội công dân” indicates the following main connotations:

- It is a sector of citizens (e. g. a community or organization) in a society, which can be considered the first legal stratum. It means that without his/her civil rights and obligations and citizenship as regulated by the law of a nation, a person is not included in this concept.

- The citizens organize themselves into a "society" (e. g. an association, union, or community) that operates under the state of law and is legitimate. This is the second legal stratum. As a result, illegal organizations do not belong to this concept.

- Civil organizations and communities are multiple hence their relations have to be regulated by the law, which is the third legal stratum. These constitute other indirect connotations of "civil society" such as civilization and urban dwellers. 
Therefore, it is my recommendation that "xã hội công dân" should be used to connote "civil society" instead of "xã hội dân sự". ${ }^{2}$

\section{Why is there a Civil Society?}

Looking at the ideological, theoretical and practical development of the state of law, it can be said that: The sovereignty of citizens over the state is an objective reality, as citizens decide the form and organization of a state by authorizing their power to a number of representatives who run it on their behalf. The sovereignty of citizens over the state is a prerequisite of the state of law.

The sovereignty of citizens is manifested in economic, political and social terms as follows:

- Citizens have their respective economic status, based on a particular ownership of the means of production and possessions.

- Citizens are permitted to organize and contribute to overall affairs of the state (which are read as the right to elect, self-nominate and participate in state management).

- Citizens are allowed to supervise the activities of state authorities.

- Citizens have the right to express their will and realize their interests or those of their community (political rights such as freedom of association and assembly, of demonstration and speech, freedom of religion and belief).

- Although part of it is delegated to the organization of the state and fulfilment of public functions, the power of citizens is fundamentally preserved and is supreme.

- The evolution of mankind is simultaneously an ongoing struggle to claim civil sovereignty. While this struggle has gained significant achievements, civil sovereignty remains a critical issue to be solved along with social development.

To oppose and remove feudal authoritarianism and safeguard the liberal rights of people, thinkers influenced by Enlightenment insist on a civil society as a basis of the state of law. The concept of civil society as an independent entity in relations to the state is criticized zed in the history of Western ideas, and though it is defined in different ways by thinkers from France and Germany,

\footnotetext{
${ }^{2}$ Hereafter referred to as "civil society".
} 
there is a common attempt to clarify the problematic and complicated relations between public and private sectors, individuals and society, social ethics and individual interests, and between personal desires and social concerns. Despite these varying trends, the idea of civil society appeals to many ideologists, who considered it to be a collection of the desires of both society at large and each individual. Civil society, therefore, includes a wide range of moral ideas on social order, or at the very least harmonizes the conflict between the personal needs and interests with those of the society at large.

The concept of civil society stems from the theory of natural law, although its development is increasingly sophisticated, even present in certain aspects of medieval Christian ideology. The ideological history of civil society begins with philosophers from the Age of Enlightenment to Karl Marx and the subsequent political and legal ideologists. The social need for civil society is the need to revert to manageable aspects of social life which emphasizes voluntary civil unions. Civil society in modern capitalist states is a part of the communal process of continuous struggle for freedom, equality and justice, avoiding being compromised by both the market and the state.

\section{Civil Society in Marxism}

According to Marx, the term civil society was introduced in the $18^{\text {th }}$ century, when ownership relations had evolved beyond their communal form as in ancient and medieval times. Marx claimed that family and civil society were the prerequisites of the state:

"Family and civil society are the bearers of the state (in the widest sense - PXS); they are the existence of will, they are the state's mode of existence. Family and civil society form the state."

Marx's notion has a great significance in terms of methodology in thinking on the state and choosing a model for social development. According to Marx, civil society is not within the political realm, but all of its activities affect the state. Because of this, the institutions (organizations) of civil society bear certain political forms. As such, in building a civil society, it is necessary to recognize its independence and objective role for the state (i.e. assigning various fields of human activity) on the one hand, and recognize its political forms on the other hand.

\footnotetext{
${ }^{3}$ Marx/Engels (1995), 314-315.
} 
In terms of freedom, it transforms the society's supreme bodies into its dependents, and even nowadays whether a state is free or not depends on "the extent by which the state's freedom is limited" vidual as a member of civil society who, therefore, is the basis, the premise of a political state. The state acknowledges this accordingly in terms of human rights."

\section{Civil Society as a "Non-state" Area}

Marx held that, "political emancipation means freeing civil society from politics, even from the appearance of a certain universal content." ${ }^{6}$ At that point, "man, as a member of civil society, the apolitical man must appear as a natural man." Thus, the birth of civil society, the "political emancipation or turning of man into a member of civil society, an egoistic and independent individual on the one hand, and into a citizen of the state, a legal entity on the other hand" ${ }^{\prime}$ is major historical progress in medieval times, when social life is uniform to political life.

\section{On the Importance of Civil Society}

Karl Marx wrote, on the importance of civil society, that "civil society is the actual center, the actual arena of history in its entirety,"9 and that "political revolution is a revolution of civil society." ${ }^{10}$ This shows that any modern political party or a modern social force striving for victory must win the ultimate battle in civil society. Although Marx studied civil society in his contemporary historical context, the universal values of his standpoint remain in effect until today. When addressing civil society, Marx confirmed that it is the fruition of the capitalist development (in Marx's time, capitalism is the highest socio-

\footnotetext{
${ }^{4}$ Marx/Engels (1995), 554.

${ }^{5}$ Marx/Engels (1995), 554.

${ }^{6}$ Marx/Engels (1995), 554.

${ }^{7}$ Marx/Engels (1995), 554.

${ }^{8}$ Mác/Ăngghen toàn tập, tập 1, CTQG, H, 1995, tr.557.

${ }^{9}$ C. Mác-Ph. Ăngghen, Tuyển tập, tập 1, Nxb Sự thật, Hà Nội, 1980, tr. 299. (Hệ tư tưởng Đức).

${ }^{10}$ Mác/Ăngghen toàn tập, tập 1, nxb CTQG, H, 1995, tr.554.
} 
economic form), but he remained faithful to the term "in any era"; as long as the state exists, civil society will be its basis. Civil society, wrote Marx, "always refers to a social organization that stems directly from production and commerce and, in any era, is the basis of the state and of the ideological superstructure as well." 11

\section{Definition}

Civil society is a system of civil organizations, communities and their relations, operating within the national law in order to realize individuals and characters, connecting individuals to the social system, and strengthening and protecting communal interests. At the same time and through organizations and communities, civil society coordinates with the state, ensuring that the relations between the state and society remain balanced, stable, and optimal for sustainable development and social progress.

\section{The Structure of the Civil Society}

In terms of institutions (organizations), it includes all unions, associations, interest-based leagues (economic, political, cultural, professional, scientific, educational, entertaining, etc.). It would be insufficient, however, to refer to institutions without mentioning their interrelations, their coordinating mechanisms and other organizational and operational principles.

\section{The Position of the Civil Society in the Social System}

Civil society refers to the institutions that "stand next to" (in the words of Karl Marx) those of the state (e.g. parliament, government, president, the judicial body, local administrations, etc.). In other words, the institutions of civil society are relatively independent; they do not depend on and are not state organizations, nor are they manufacturers or businesses.

\section{The Characteristics of a Civil Society's Activities}

Important factors to characterize institutions of the civil society are a common identity of the respective group or community, (financial) self-reliance, selfmanagement, voluntarism, and diversity in organizational forms. Depending

${ }^{11}$ C.Mác/Ph.Ăngghen: Tuyển tập, tập IV, Nxb Sự thật, Hà Nội, 1984, tr. 362. 
on the model of the political system, civil society's organizations can be within or outside of the political system.

\section{Functions of Civil Society}

Some basic functions of the civil society are:

- Socializing individuals, realizing personalities, connecting individuals to the social system, strengthening and protecting the communal interests.

- Providing a basis for the state and coordinating with it, supplementing and replacing it (in certain areas, usually where the state cannot perform with higher efficiency than civil society), verifying, and perfecting the state activities, thereby balancing and stabilizing state and social activities.

Nowadays, the civil society is among the three most fundamental pillars of social development: If a market economy is the prerequisite for national development, and a state of law is what directly determines development, then the civil society is a guarantee for development. The final goal of a modern civil society is the development and perfection of individuals, which is the condition for the development of community, society, and humanity. In terms of development, civil society is the place where a nation's social capital is formed, accumulated and preserved. The development of civil society aims at humanity's common progressive values, while at the same time depends on the periodic characters and specific historical backgrounds of each nation; it depends also on the forms and types of state and on their political system.

In summary, a civil society is a voluntary collective realm of activities whose purpose is to share common benefits, goals, and values. Theoretically, their organizational forms differ from those of the state, family, and the market; although in reality, the frontiers between the state, civil society, family, and the market are often complicated, ambiguous, and reciprocal. The nature of civil society, as addressed above, is the relationship between individuals, between individual and community, and between individual and the state, in other words citizens in their forms of community.

\section{Models of Civil Society}

There is a wide range of models of civil societies, and they can be summarized into three major types:

- The liberal model understands the civil society as opposition to the state, and is observable in countries like the US, or UK. 
- The democratic socialist model sees the civil society as a unifier of state and society. Its proponents are modern democratic socialist parties, mainly from Scandinavia and Germany. This model is reflected in the definition of the "social state". The state is concerned with all social groups, and builds interactions and unity between itself and civil society.

- Whether a specific Soviet civil society actually exists or not has long been a subject of debate between international and Soviet scholars. In general, most scholars recognize its existence, but due to a lack of official acknowledgement and proper regulative legislations, Soviet civil society has suffered from a number of derailments and weaknesses.

Studying the issue of the civil society provides us with a methodological basis to study international socio-political entities in general and those in Vietnam in particular.

\section{Negative Manifestations of Civil Society}

Beginning with the development of production and division of labor, social structures diversified increasingly in terms of professions, interests, and value orientations. The formation of groups with different interests is hence inevitable. However, it is not inevitable that a certain group is only pursuing its own interests and violating those of other groups and/or the state; this stems from egoistic goals. "Interest group" is a group that seeks to maximize its own interests and, in the process, violates the common interests of society or those of other groups. Interest groups cause social fragmentation and corrupt social unity and consensus. Should all groups act in such a way, then the civil society "becomes a battlefield where everyone is against everyone" (Hegel).

Due to limited resources and lax organization, many civil society organizations seek for sponsorship from business or foreign entities, thus creating financial dependence. These organizations fail to achieve their intended goals on the one hand, and become dependent on, or are even used to accomplish the wicked purposes of economic or political forces on the other hand.

Some domestic civil society organizations may be formed "unnaturally" as partners of foreign NGOs, which are also formed in order to realize the malicious goals of certain forces. Without adequate legislation to prevent such organizations, social insecurity may ensue, especially in the context of global integration when the freedom of speech, freedom of press, and freedom of assembly are not only universal values but also binding requirements in interna- 
tional commitments. Even though a civil society may be considered a place "external to politics", a number of groups have been shifting towards the political realm for the sake of self-interest rather than the benefits of its members. These groups rely on sacred values and sentiments, such as national and ethnic bonds, religious beliefs, human rights and dignity etc. to promote hate, violence, and hostility against the state, with measures ranging from peaceful to radical that far exceed the scope of a civil society organization.

Quite a large number of such groups have been prepared to act as "insiders" for foreign enemies. Some with economic influences may utilize money or other substances to seduce high-ranking political figures, manipulate the policy making process to serve their own interests, violating the principle of nonprofit. For organizations with state funding (several socio-political and other social organizations), they tend to foster superficiality, authoritativeness, and derailing from the nature of civil society.

There are limitations and negativities to every realm and aspect of social life. In the case of a market economy, it is the willingness to sacrifice everything for "maximum profit", even if it means the compromise of national interests, a widened rich-poor gap, foul play in business, and illegal competition. Even in a state of law, such plights as bureaucracy, corruption, policy exploitation and manipulation, and abuse of power persist.

These negativities (or shortcomings) of a market economy, of a state of law, or of a civil society as aforementioned are understandable and have yet to be eradicated. But they cannot derail the developmental orientation of the Vietnamese people, and cannot eclipse the benefits of market economy, state of law, and civil society; and as a result, we should not be "afraid" of a market economy, state of law, and civil society. It is necessary for the state to introduce a legislative system to regulate and manage civil society. Only after clear legislation is created can we limit or eradicate organizations that undermine state and society. 


\section{What are the Characteristics of the Vietnamese Civil Society?}

\section{Universality and Particularity}

The theoretical issues discussed above on civil society and socio-political organizations will serve as a basis for us to examine the civil society in Vietnam. In Vietnam, the system of social and socio-political organizations, despite their being atypical, bear the trait of universality. It means that they are created and exist firstly because of the inherent needs of the civil society itself; even during the era of national liberation, participating in socio-political organizations was an urgent need of all societal classes. Moreover, historical areas notwithstanding, the people's need to assemble into groups is greatly diverse, especially in the modern era, and this requires a corresponding shift in the political thinking of the state, stemming from the needs, desires and benefits of the people.

As such, it is reasonable to say there is in fact a civil society in Vietnam. In terms of organization, there are around 500 organizations (associations) operating nationwide; around 3.000 operating locally, and tens of thousands more on the district and grass root levels. They are structured as follows:

- Socio-political: The Vietnam Fatherland Front (VFF) and other sociopolitical organizations are within the political system and act as the core of Vietnamese civil society. The VFF is a socio-political organization with some 50 member groups and many prominent individuals, among these are five socio-political organizations that have been codified by the constitution and by law.

- Economic: productive, business and service associations (professional associations) such as associations for steel, cement, construction, architecture, sugar cane, coffee and cocoa, rice export, etc.

- Scientific and technological: union of scientific and technological associations, private research groups, etc.

- Social: socio-professional organizations, groups concerning common interests, charity, humanitarian aid, hospitality, gender, etc.

- Non-governmental organizations (NGOs) in Vietnam.

Among these organizations are their coordinative relations, principles, and mechanisms. Of course, the criteria for classifying these organizations are only relative. In Vietnam, the creation of the socialist republic is closely related to a struggle for national independence and de colonization. The VFF and other socio-political organizations were formed under the mobilization and arrange- 
ment of the Communist Party of Vietnam, intertwined with it in that struggle and answering to its leadership. In other words, the sense of citizenship and political awareness had matured along with the struggle for national liberation. In that process, the formation of social and socio-political organizations bore the trait of collectivism as Vietnamese people from all walks of life were mobilized against imperialism and feudalism, and the interests of all classes were first and foremost connected with the process of political struggle. Such positions and features strengthened when the CPV became the ruling party and are persisting until today. In the new context, although the VFF and other socio-political organizations retain their political functions, their social capacity is increasingly expanding and diversifying. This proves that the VFF and other socio-political organizations play a crucial role as core forces of Vietnam's civil society.

\section{Challenges for the Civil Society}

When civil societies first exist as representatives of and protectors of the interests of a certain class or group in their relations with the politically/economically dominant lords, or even with the state, they are not immediately recognized as legal. Because of certain interests, the state often prohibits the existence and activities of these organizations. Despite its prominence in the $18^{\text {th }}$ and $19^{\text {th }}$ century, the term "civil society" from time to time ceased to be widely used. At times, the major theories of Western thinkers focused only on the complex relationship between the state and the market. As such, "society" was no longer under the spotlight. After the collapse of the Soviet Union and Eastern European socialist states, people began to doubt the "role" of civil society. However, in contrast to that skepticism, scholars found that the USSR and Eastern European states did not accept the civil society, that these states were highly centralized with a too feeble civil society, unlike Western states with the same level of development. Perhaps it was this that caused those states to collapse.

However, studying the experiences with the respective civil society is adequate not only for Eastern Europe but also for developing nations. The EU shows great interest in this matter. The "Civil Dialogue", initiated with the 1990 Commitment, was its first attempt to facilitate social institutions - so 
that actors from governments and business lobbies are not the only audible agents in the policy making in Brussels. The EU has also commenced the regulation of frequently conflicting interests among NGOs and other civilian groups. There has been a shift in the awareness in the EU, which now holds that state governments and international institutions should be more open toward civil society institutions.

It is industrialization that encourages the assembly of groups, of organizations with large numbers of people and collectivism, privately at first but publicly later on. These organizations are formed to counter the power of laissezfaire ideologists and business owners, and consist of labor unions, farmer and consumer associations. The unions' activities range from demanding higher wages, fewer working hours, benefits for laborers, job insurance, enterprise management, and production contracts. They consist of workers that are not insured, who are individually poorer and weaker than the entrepreneurs. Whether a union could stand firm depends on their unity.

At first, unions were suspected of violating the scope of legal operation. Early $19^{\text {th }}$ century English labor law only allowed workers to individually sign contracts with entrepreneurs, in which each party was considered an equivalent contractual party.. But in reality, since workers' capacity to negotiate is smaller than that of business owners, employees tried to balance the deal by unifying into a coherent front to ask for better terms. The employers, in turn, asked for state intervention to prohibit such associations. The British Parliament responded with a series of new legislations and declared that any association founded as a way to achieve equal standing in a collective negotiation with business owners would be illegal. The situation was much more dire in France, where there was a time when the state imposed heavy punishment on the unions which were considered rebellious. In the US, unions were also considered criminal organizations.

But with the development of the industrial society, the state could no longer resist the pressure of labor unions and the struggle by members of the "middle class". The existence of labor unions and of other civil society organizations was tolerated, accepted and then acknowledged. But Western democracies, even having accepted the legitimacy of these groups, still eradicated groups that are deemed "suspicious" or "disrupting to the social order". The skepticism of nations toward civil organizations was not demonstrated solely by absolute prohibition. It also introduced rules and limitations to impinge or con- 
trol the operation of these organizations. Hence, civil organizations depended on many bindings: on their objectives and those of the state. They sometimes had to adapt to the established institutional and structural forms. In some countries, while socio-political organizations are not meant to be formed as opposition, the government's policies and agendas put them in an oppositional stance with the state.

In the West, socio-political organizations can freely be formed and operate within the law today as a result of long lasting political conflicts. In developing countries, where many incompetent governments exist, governments usually do not take interest groups seriously or are tired of them, because of the fact that they often have to listen to the comments, criticisms and condemnations made by these groups about their incompetence. But their voices are the vein of society whose resonance can still be heard by governments. In a number of cases, governments must adjust their policies because of the criticisms by interest groups. The recommendations by environmental groups, for instance, initially irritated most countries' leaders, but in time they gradually had to pay greater attention to ecological matters, which have become a global responsibility.

\section{How Does the State of Law Manage the Civil Society in Vietnam?}

First of all, it is necessary to reaffirm that the civil society is an objective social structure rather than a political instrument that can be freely utilized or disposed of. Past experiences have shown that state regimes which are "hostile" toward the existence of a civil society will eventually be toppled it.. In recent decades, the world witnessed various "color revolutions" which caused many regimes to topple, even resulting in the complete collapse of governmental order or entire states. Among the causes are weaknesses, or even a complete lack of a civil society in those countries. The inadequacy of civil society in those countries drives their state regimes toward authoritarianism (which in turn would further undermine civil society). This leads to the degradation of the state itself. The systems of government in those countries were sluggish, nepotistic, corrupted, dictatorial and authoritarian; their economic and sociocultural performances were bad, the country was internationally isolated; and its people discontent. Even a small number of groups can suffice to take ad- 
vantage of this discontent, and in coordination with external intervention they can mobilize the people to instigate protests or anti-state violent subversion, despite the great cost it would incur. If a civil society is strong enough, it may prevent the state from becoming so degraded that subversion becomes inevitable, and it would also help to prevent and preclude domestic and foreign conspiracies driven by self-interest.

The civil society is the source of human and social capital of Vietnam in general, and of the party and the state in particular. Loosening state management over civil society will deprive us of the human resources and social capital needed for the construction of a state of law and to foster national development as desired.

In the past struggle for national independence, each particular action had to be in the service of the supreme interest of the nation. National independence was the precondition for any further achievement in the realm of interests of the diverse social classes and groups. But today, as the national independence of Vietnam is secured, the further development of Vietnam must take a step forward. Today the ultimate goal - national development - can only be achieved by realizing the interests of various social classes and groups. In the contemporary history of Vietnam we can observe two different trends with reverse priorities: In the past: "no country - no home", and now "prosperous people - powerful nation". Thus, the existence of civil society is first and foremost determined and promoted by the interests of its members (i.e. citizens, participants).

Due to the complexity of socio-economic life and the diversity of needs and interests, the assemblage of civil society organizations must be correspondingly diversified, from the VFF and socio-political organizations to socio-professional organizations, clubs, NGOs, etc. As a result, diversifying the forms of civilian assemblage is a condition for the success of and also a guarantee of the party's leadership in the future.

The state manages civil society through legislations, policies, and other tools. At present, it has promulgated a number of laws regarding the civil society in Vietnam, but there is still a lack of adequate legislations, even the most basic ones, for the management of the civil society. This lack creates more difficulties for governance, especially for functional authorities, which due to having no relevant legislations to refer to, have problems and uncertainties in how to deal with legal (registered) and illegal (unregistered) organiza- 
tions. The registration itself is difficult. Which organization can register, and which cannot? Why so? Currently, even those that can register have only registered in documents, by which they state their purposes and principles. But civil society is not a single organization and cannot be limited within purposes and principles; it has a much larger scope and is related to factors like governance, political and social system, other associations and the general provisions of civil rights. Since there is no association law yet, the state is unable to manage these affairs, and sanctions for the organizations' wrongdoings cannot be imposed. In reality, state agencies were unable to determine whether protesting against China's placement of an oil rig on Vietnam's continental shelf, or the declaration of a group to form an organization, is illegal or not (provided that their purposes and principles are not unconstitutional).

Past experiences in economic development also showed that when we had no intention of building a market economy, there was no law on economic activities, and state authorities were unable to determine whether the conducts of $\mathrm{Ba}$ Thi, Kim Ngoc, or those who traded goods between provinces, were against the law. We can only imagine the challenge that the authorities had to face when pursuing and confiscating inter-provincial shipments back then, or when the confiscated goods from petty merchants or bought from state-owned shops were just resold on the street with a higher price ("con phe", as it was called)! Not to mention issues related to tariff and penalties. The lack of legislation is also what has been challenging Thailand's authorities in the recent cases of surrogate pregnancy. But as soon as there are clear guidelines and legislations, things become much easier. The same is true for state governance and civil society. Civil organizations or communities operating legally shall have permission to do whatever is not prohibited by the law, and those who violate the law must face legal punishment. This requires an imperative perfection of the legal system on civil society, in which association law holds a key role.

The perfection of the legal system on civil society will not only reflect the fact that state governance capacity has met the demands of objective reality, helping authorities do their lawful assignments, but also guarantee civil rights, security, order, and promote social development. Currently, due to the lack of legislation, civil society organizations operate in a disorganized manner, in which some even take advantage of legal ambiguity to conduct anti-state activities, producing serious harm to national development. Authorities are faced with multiple difficulties when dealing with such groups; this unknowingly 
casts upon them a sense of "allergy" or prejudice toward civil society. When legal clarity is present, these challenges will largely be overcome. It is foreseeable, though, that after such legislations are enacted, many new civil society associations and organizations will be established, just like the mushrooming of enterprises after the introduction of the Law on Enterprises. Just as in the case of the market economy, legitimate and effective organizations that operate legally persist, while the rest go into "bankruptcy". Only after such a period can we hope for a true civil society in Vietnam.

It is also necessary to note that the legal system, especially association law, will concern a number of extra-governmental organizations that include political parties, socio-political organizations, and other social organizations. Therefore, we should have a clear definition and distinction between these forms of organization:

- Political party refers to political entities whose purpose is to take over control of the government and exercise state power. Such great purpose usually impels parties to have a coherent organization, high level of discipline, and principles that are faithful to their ideals, guidelines, and strategies.

- Socio-political organizations are groups that operate for the benefits of particular social groups and communities, through measures that can have influence on the government and political parties (without having a goal for taking over governmental control or participation).

- Social organizations are groups of members who strive to achieve common purposes of the group, society, or the community without goals to have direct influence, impact on the policy making process of the state or political parties (e.g. association for gardening, charity, poetry etc.).

Of course, such distinction is also relative. When there are changes in the socio-economic situation, social needs, or purposes and methods of operation in accordance with the national legal context, a social organization may turn into a socio-political one, and a socio-political organization may turn into a political party. In Russia, following the collapse of the Soviet Union, hundreds of political parties came into being. Most of them have ceased to exist, and some went on to become social organizations. This is a noteworthy issue in the governance of Vietnam regarding its civil society. 


\section{Recommendations}

- Awareness: Conducting research, exchange between leaders, managers, scholars, and citizens in order to have an accurate and scientific awareness of civil society.

- The demand for a civil society in Vietnam is great and objective. The Communist Party should advocate the construction, development, and guidance of the Vietnamese civil society.

- The National Assembly should quickly embark on proper legislation regarding civil society, with priorities on association and demonstration law to provide a basis for state governance of the civil society.

\section{References}

Đào Trí Úc (n.y.): Bước đầu tìm hiểu về xã hội công dân (A preliminary research on civil society, research project at Institute level of the Institute for State and Legal studies). Hanoi.

Encyclopedia Publisher (2005): Từ điển Anh-Việt (English-Vietnamese Dictionary). Hanoi.

Hall, John R. (1995): Civil society. Theory, History, Comparison. Cambridge.

Lê Văn Quang/Văn Đức Thanh (eds.) (2003): Quan hệ giữa nhà nước và xã hội dân sự Việt Nam-Lịch sử và hiện tại (The relationship between state and civil society in Vietnam - Historical and current issues). Hanoi.

Lipson, Leslie (1965): Những tranh luận lớn về chính trị (The great issues of politics: an introduction to political science, translated by the Vietnamese Insitute for Political Science). Englewood Cliffs.

Meny, Yves (1991): Chính trị học so sánh (Comparative Political Science, translated by the Institute for Political Science). Paris.

Phan Xuân Sơn (ed.) (2003): Các đoàn thể nhân dân với việc đảm bảo dân chủ cơ sở hiện nay (Civil organizations and the maintenance of grassroots democracy today). Hanoi.

Phan Xuân Sơn/Quan điểm của (2005): C.Mác về Xã hội công dân (K. Marx’s ideas on Civil Society). In: Journal of Theoretical Discussions, Danang, $6^{\text {th }}$ issue (73).

Seligman, Adam B. (1995): The Idea of Civil Society. Princeton. 
Truth Publisher (ed.) (1995): Mác/Ph. Ăngghen. Toàn tập ((Marx and F. Engels, collected works). Tập IV ( $4^{\text {th }}$ volume). Hanoi.

Truth Publisher (ed.) (1995): Mác/Ph. Ăngghen. Toàn tập (Marx and F. Engels, collected works). Tập I (1 $1^{\text {st }}$ volume). Hanoi. 